Article

\title{
Comparative Life-Cycle Assessment of a High-Rise Mass Timber Building with an Equivalent Reinforced Concrete Alternative Using the Athena Impact Estimator for Buildings
}

\author{
Zhongjia Chen ${ }^{1}$, Hongmei Gu ${ }^{2, * \mathbb{D}}$, Richard D. Bergman ${ }^{2}$ and Shaobo Liang ${ }^{2}$ \\ 1 School of Technology, Beijing Forestry University, Beijing 100083, China; chenzhongjia@bjfu.edu.cn \\ 2 Forest Service, Forest Products Laboratory, United States Department of Agriculture, \\ Madison, WI 53726, USA; richard.d.bergman@usda.gov (R.D.B.); sshliang@gmail.com (S.L.) \\ * Correspondence: hongmei.gu@usda.gov
}

Received: 5 May 2020; Accepted: 3 June 2020; Published: 9 June 2020

check for updates

\begin{abstract}
Buildings consume large amounts of materials and energy, making them one of the highest environmental impactors. Quantifying the impact of building materials can be critical to developing an effective greenhouse gas mitigation strategy. Using Athena Impact Estimator for Buildings (IE4B), this paper compares cradle-to-grave life-cycle assessment (LCA) results for a 12-story building constructed from cross-laminated timber (CLT) and a functionally equivalent reinforced concrete (RC) building. Following EN 15978 framework, environmental impacts for stages A1-A5 (product to construction), B2, B4, and B6 (use), $\mathrm{C} 1-\mathrm{C} 4$ (end of life), and D (beyond the building life) were evaluated in detail along resource efficiency. For material resource efficiency, total mass of the CLT building was $33.2 \%$ less than the alternative RC building. For modules $\mathrm{A}$ to $\mathrm{C}$ and not considering operational energy use (B6), LCA results show a $20.6 \%$ reduction in embodied carbon achieved for the CLT building, compared to the RC building. For modules $\mathrm{A}$ to $\mathrm{D}$ and not considering B6, the embodied carbon assessment revealed that for the CLT building, $6.57 \times 10^{5} \mathrm{~kg} \mathrm{CO}_{2}$ eq was emitted, whereas for the equivalent RC building, $2.16 \times 10^{6} \mathrm{~kg} \mathrm{CO}_{2}$ eq was emitted, and emissions from CLT building was $70 \%$ lower than that from RC building. Additionally, $1.84 \times 10^{6} \mathrm{~kg}$ of $\mathrm{CO}_{2}$ eq was stored in the wood material used in the CLT building during its lifetime. Building material selection should be considered for the urgent need to reduce global climate change impacts.
\end{abstract}

Keywords: whole building; cross-laminated timber (CLT); environmental impacts; embodied carbon; cradle-to-grave

\section{Introduction}

The building sector is one of the major industries producing a large amount of greenhouse gases [1,2]. It contributes about $36 \%$ of global energy use and $39 \%$ of energy-related carbon dioxide $\left(\mathrm{CO}_{2}\right)$ emissions [3]. Therefore, the building sector represents significant potential for reducing emissions and mitigating global climate change.

Two major approaches are currently being adopted to reduce environmental impacts from the building sector. One is selecting materials wisely, and the other is optimizing energy use during the service life of a building [4,5]. Hafner [1] calculated through life-cycle analysis that the operational phase accounts for $45 \%$ to $80 \%$ of total carbon emission, depending on the energy standard with which the buildings are built. That leaves $20 \%$ to $55 \%$ of total carbon emissions related to materials used in buildings and their embodied carbon. Therefore, the greenhouse gas (GHG) emissions of whole buildings can be significantly influenced by the selection of construction material. Considering the 
large amounts of standardized products used, such as concrete, masonry, and steel, the process of design and construction must consider environmental impacts. Concrete is responsible for $4 \%$ to $8 \%$ of the world's $\mathrm{CO}_{2}$ emissions [6]. The steel industry generates between $7 \%$ and $9 \%$ of direct emissions from the global use of fossil fuels [7]. Recently, research has focused on developing materials with low $\mathrm{CO}_{2}$ emissions that can mitigate climate change, either by reducing carbon emissions or storing carbon for long periods of time [8].

Wood construction of various types, rather than steel, concrete, or masonry construction, has a long history in many countries [9]. Now wood construction is becoming popular for mid- to high-rise buildings, because of the rapid growth of mass timber (MT) products, such as cross-laminated timber (CLT) $[10,11]$. Wood buildings are considered lower carbon (less fossil fuel intensive) constructions than non-wood buildings [12-15]. Wood and mass timber products have been demonstrated with benefits in reducing global warming potentials, only if they are sourced from sustainably managed forests. Building with wood contributes to the critical benefits related to mitigating climate change, because wood can not only be used as a substitute for other materials to reduce GHG emissions, but also has a unique function of storing large amounts of carbon in the building structure, a property other materials do not possess [16]. In addition to serving as a construction product during a building's lifespan, after the building's service life, the wood can be re-used in other construction, as feedstock for another engineered wood product, or, as a last resort, burned for energy as a substitute for fossil fuel [17-19]. CLT is just one of many MT products available for construction, including glulam, dowel-laminated timber (DLT), nail-laminated timber (NLT), and massive plywood veneer, which are used in conjunction with CLT primarily for multi-story buildings.

As mentioned, CLT is a new wood structural product that can be used for residential, commercial, and institutional buildings in a cost-effective way [20]. It is a form of large timber board, built up of layers of planks with adjacent layers at right angles to each other. It usually consists of three, five, seven, or nine uneven layers of boards [21]. As an engineered timber product, CLT is used primarily as a structural building material, but can also be used as exterior wall material and secondary structural material, such as for interior walls and floors [8]. It is also now practical to use computer numerical control (CNC) technology to cut openings of different sizes and shapes on CLT panels for windows and doors with precision value added [22].

Research on MT, including life-cycle analysis, has been a focus for the past decade $[23,24]$. According to Darby [25], CLT has notable effects on reducing GHG emissions, regardless of its final disposition after the building reaches the end of its serviceable life. Robertson [22] conducted a cradle-to-gate LCA analysis sourcing from BEES 4.0, Athena EcoCalculator, CORRIM and US LCI. He showed that maximizing wood use (including glulam and CLT) in buildings could reduce the global warming impact by $71 \%$ when compared to concrete. Skullestad [26] followed the ISO standard provided framework and calculated the climate change impact (CC) with the ReCiPe method using SimaPro v7 software equipped with Ecoinvent v3.2 database. Skullestad reported a 34\% to $84 \%$ GHG reduction from four building construction types by substituting wood (glulam and CLT) for steel and concrete. Milaj [27] studied six cases of commercial buildings using cradle-to-grave life-cycle analysis with Athena Impact Estimator for Buildings to evaluate the environmental benefits of using wood in place of concrete and steel, and results showed an average GHG reduction from wood substitution of $60 \%$ across the six buildings. Gu and Bergman [28], collaborating with the Athena Sustainable Material Institute and the University of Massachusetts, conducted a whole building life-cycle assessment (LCA) on a four-story educational building called the Design Building, which used a large amount of CLT in the roof, floor, and stair-core wall panels. They developed the first Environmental Building Declaration (EBD) in the United States, and the building ultimately achieved LEED credit for its reduction in LCA impact.

This paper aims to investigate the environmental impacts of a MT high-rise multi-functional building, compared with its more traditional RC counterpart, using Athena Impact Estimator for Buildings (IE4B). There are two commercially available software tools to perform Whole Building LCA 
(WBLCA) focusing on US data. They are Tally and IE4B. Tally is an Autodesk Revit application to help architects and engineers to compare environmental impacts of different building designs. Tally extracts data from Revit models to calculate embodied impacts. We chose IE4B, because we do not have the Revit model, but only material take-off (Table A1) data from the architects. The embodied carbon for both buildings is analyzed and reported, to compare their environmental impacts. Embodied carbon refers to the GHG emissions from the life-cycle stages of the whole building except for operational energy emissions.

\section{Materials and Methods}

\subsection{Building Design}

The building studied here was based on the Framework building designed by LEVER Architecture, a 12-story mixed-use building with $8,360 \mathrm{~m}^{2}$ floor area (Figure 1). The Framework building was the first high-rise MT building designed in the United States to obtain approval for construction. It was designed to be built for mixed-use with combined retail and public exhibition on the ground floor, five levels of office, and 60 units of affordable housing. The framework's structural system was to be made from glulam columns and beams, and the floors and walls were from large amounts of CLT materials. The foundation, one of the heaviest parts of the building, would have been constructed of concrete and steel rebar.

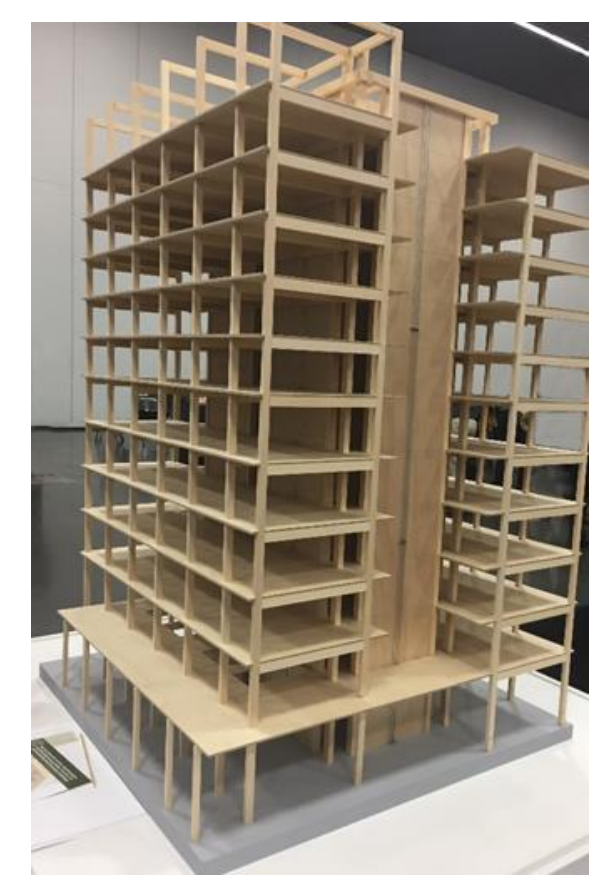

Figure 1. The building design with the cross-laminated timber (CLT) is a high-rise building structure in Portland, Oregon, USA.

\subsection{Goal and Scope}

The goal of this study was to conduct a whole building LCA using the IE4B, to estimate environmental impacts from the building materials of assemblies, construction, and the end of building life treatment during a 60-year period [29]. Comparison of the LCA was between the MT building and a functionally-equivalent RC building specifically examining the effect of CLT use in high-rise residential buildings for global climate change mitigation potential.

The system boundary was defined as "cradle to grave," which includes the product stage (A1-A3), construction stage (A4-A5), use stage (B2, B4), and end of life stage (C1-C4) [30], as shown in Figure 2. System expansion was employed to take into account the net benefits related to reuse and recycling 
of the materials and products, as well as energy recovery from materials, such as wood incineration beyond the system boundary (D).

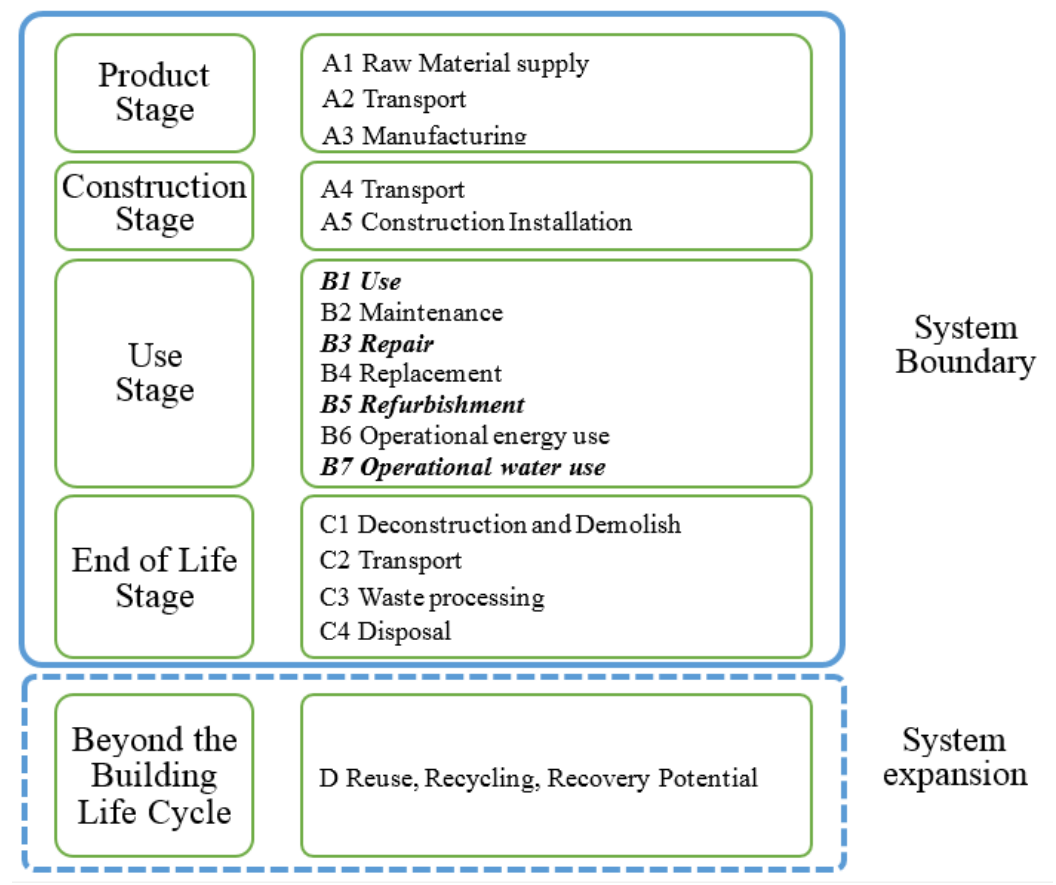

Figure 2. Assessment system boundary based on EN15978 (bolded and italicized items not included in this analysis).

For this study, several stages within Module B were excluded from the comparative LCA, because of the assumption of functional equivalence for the two buildings in their use stage and lack of empirical data for repairing and refurbishing of MT buildings and lack of water consumption data. Thus, B1-Use, B3-Repair, B5-Refurbishment, and B7-Operational Water were excluded from the analysis. Although the global warming impact from the whole building LCA comes mainly from operational energy, such as electricity and natural gas used during the building's lifetime, the two comparison buildings were designed as functionally equivalent. Thus, no difference would be shown for the operational energy impacts (B6). This analysis mainly focuses on the impacts resulting from materials and other activities.

\subsection{Software Tool}

IE4B is an open free software tool that provides a cradle-to-grave life-cycle inventory (LCI), mostly developed for north American building industries, to estimate a whole building's environmental impacts. The LCI results comprise flows from and to nature: energy and raw material inputs into the system and emissions out to air, water, and land.

Athena has developed a set of regional North American LCI datasets for major building products, such as concrete, steel, and wood products, covering $90 \%$ to $95 \%$ of the structural and envelope systems applicable to typical commercial, institutional, light industrial, and residential buildings. Additional databases related to regional electricity grids, fuel use, and transportation by various modes are taken from the U.S. LCI Database.

The IE4B tool conforms to EN 15978 standard, which includes impacts from production, transportation, construction, use, and demolition, as well as operational energy and water use. End of life (EoL) building disposal and transportation were also included in the assessment. The process of calculation for IE4B is shown in Figure 3. The IE4B tool used the "Tool for the Reduction and Assessment of Chemical and other environmental Impacts" (TRACI) environmental impact assessment method to aggregate the impacts from the LCI flows [31]. TRACI provides characterization factors for 
the life cycle impact assessment (LCIA). Characterization factors quantify the potential impacts that inputs and emissions have on specific impact categories in common equivalence units, such as global warming (GW) ( $\mathrm{kg} \mathrm{CO}_{2} \mathrm{eq}$ ), acidification ( $\left.\mathrm{AC}\right)\left(\mathrm{kg} \mathrm{SO}_{2} \mathrm{eq}\right.$ ), eutrophication (EU) (kg N-eq), ozone depletion (OD) ( $\mathrm{kg}$ chlorofluorocarbons-11-eq), smog formation (SF) $\left(\mathrm{kg} \mathrm{O}_{3}\right.$-eq), and human health (HH) (CTU).

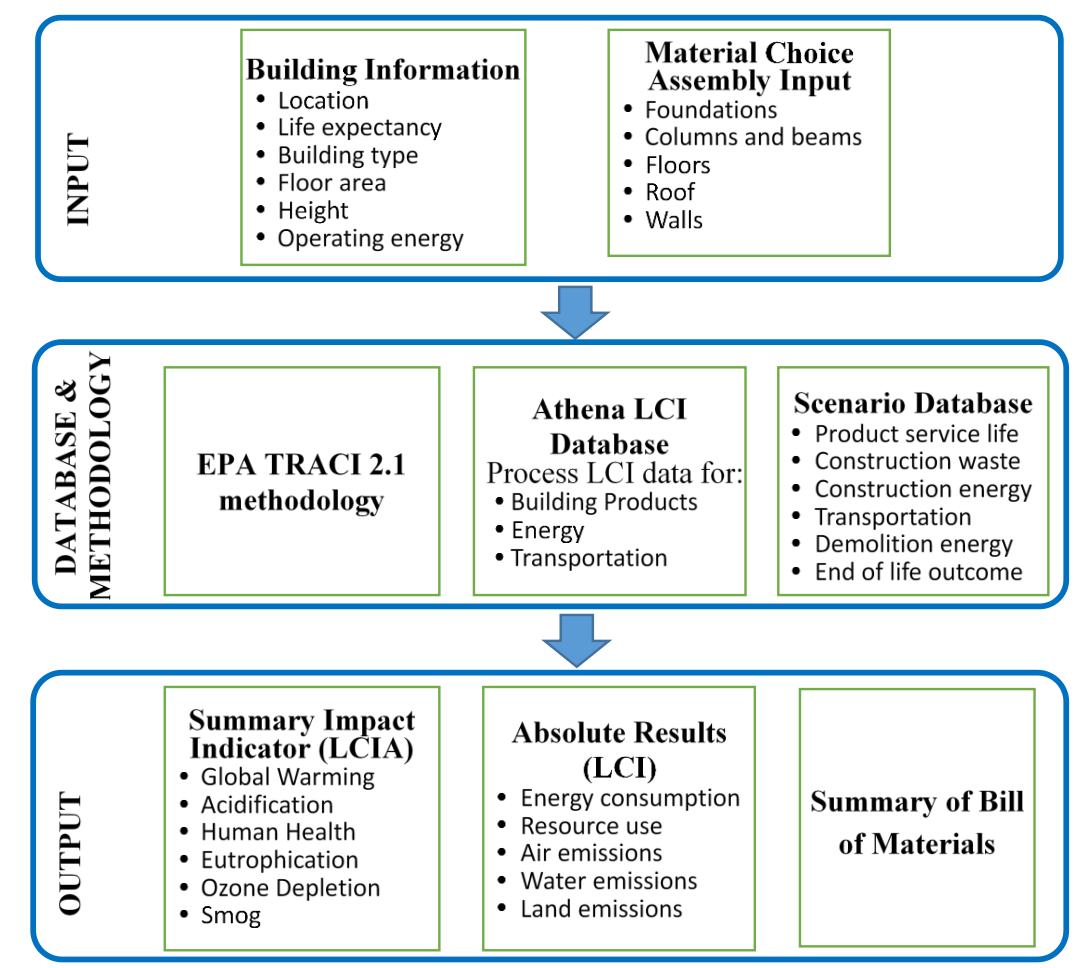

Figure 3. Athena Impact Estimator for Buildings (IE4B) calculation process based on ASMI (2019b).

\section{Results and Discussion}

\subsection{Building Material Comparison}

Material inputs for the building LCA were taken from the building's design blueprints provided by LEVER Architecture, the Framework designers. The MT and RC buildings were designed to be functional equivalent for a fair comparison. Building materials identified by the architectural blueprints are summarized in Appendix A. The total mass of the major (structural) materials for the MT Building was $5.30 \times 10^{6} \mathrm{~kg}$, whereas the RC building was about $50 \%$ heavier at $7.93 \times 10^{6} \mathrm{~kg}$.

The materials of the MT and RC buildings were grouped into different building assemblies, such as ceilings/roof, floors, foundations, columns and beams, and walls (Appendix A). Figure 4 shows the materials classified into the steel, wood, concrete, gypsum board, mortar and the rest in others based on the summary of bill of materials (BOM) used in both buildings. The most material used by weight in both buildings was concrete, which was followed by gypsum board and steel in the RC building, and wood and gypsum board in the MT building. Figure 4 shows that $1.12 \times 10^{6} \mathrm{~kg}$ more wood was used in the MT building than the RC building, and $3.8 \times 10^{6}$ and $0.22 \times 10^{6} \mathrm{~kg}$ more concrete and steel used, respectively, in the RC building. Additionally, $0.23 \times 10^{6} \mathrm{~kg}$ of gypsum board was added to the MT building to meet fire codes, which added more environmental burdens to LCA results for the MT building. Considering carbon storage in wood products and assuming wood moisture content at $12 \%$, a total of $1.14 \times 10^{6} \mathrm{~kg}$ of wood material used in the MT building translates to about $1.84 \times 10^{6} \mathrm{~kg}$ of $\mathrm{CO}_{2}$ eq stored in the building during its service life. In addition, using the mass of wood building materials and the carbon displacement factor $[32,33]$ to estimate avoided product emissions, results showed that the MT building saved $3.51 \times 10^{6} \mathrm{~kg} \mathrm{CO}_{2}$ eq of GHG emissions. The displacement factor 
computes the sum of GHG emission reduction attained per unit of wood use. In essence, building with wood avoids the consumption of about three times as much fossil fuel as a wood product needs, a substantial GHG benefit even when considering biogenic $\mathrm{CO}_{2}$ emissions. Figure 5 demonstrates the material quantity and percentage for different building assemblies in both buildings. Floors made up the largest share (by mass) of materials among all assemblies, followed by walls.

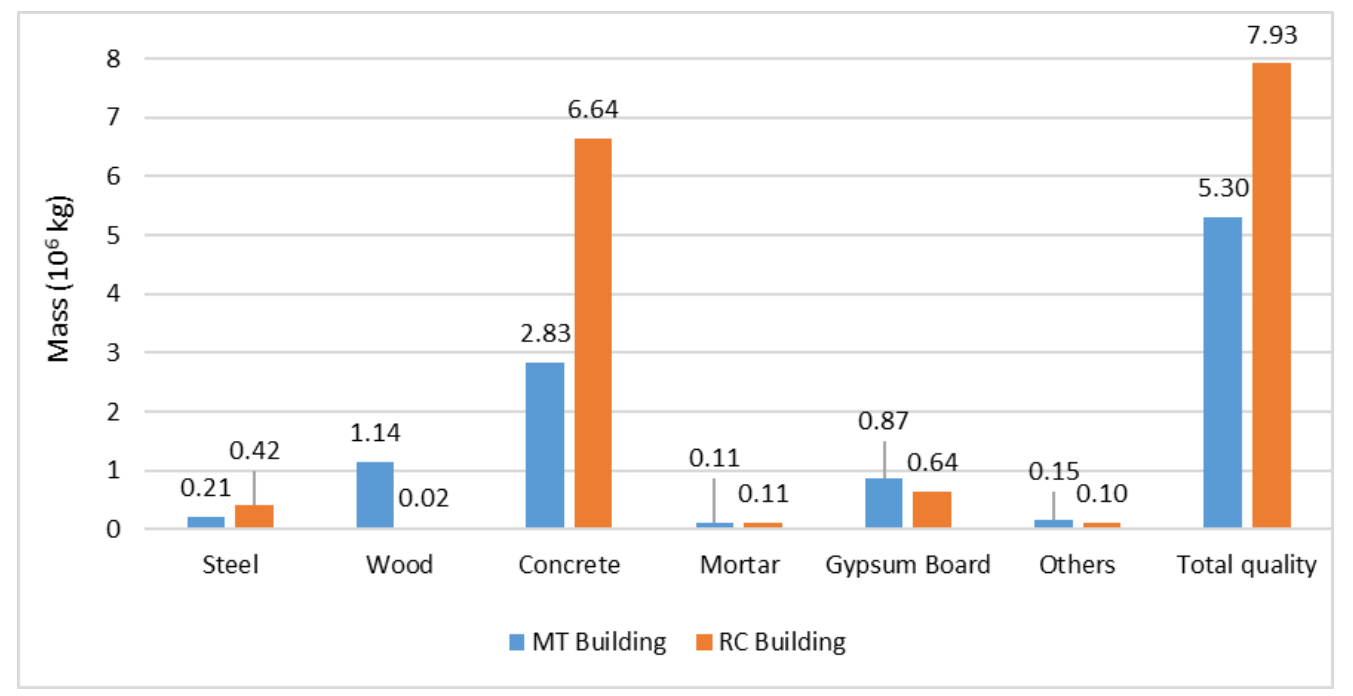

Figure 4. Mass of main materials used in high-rise mass timber (MT) and reinforced concrete (RC) buildings.

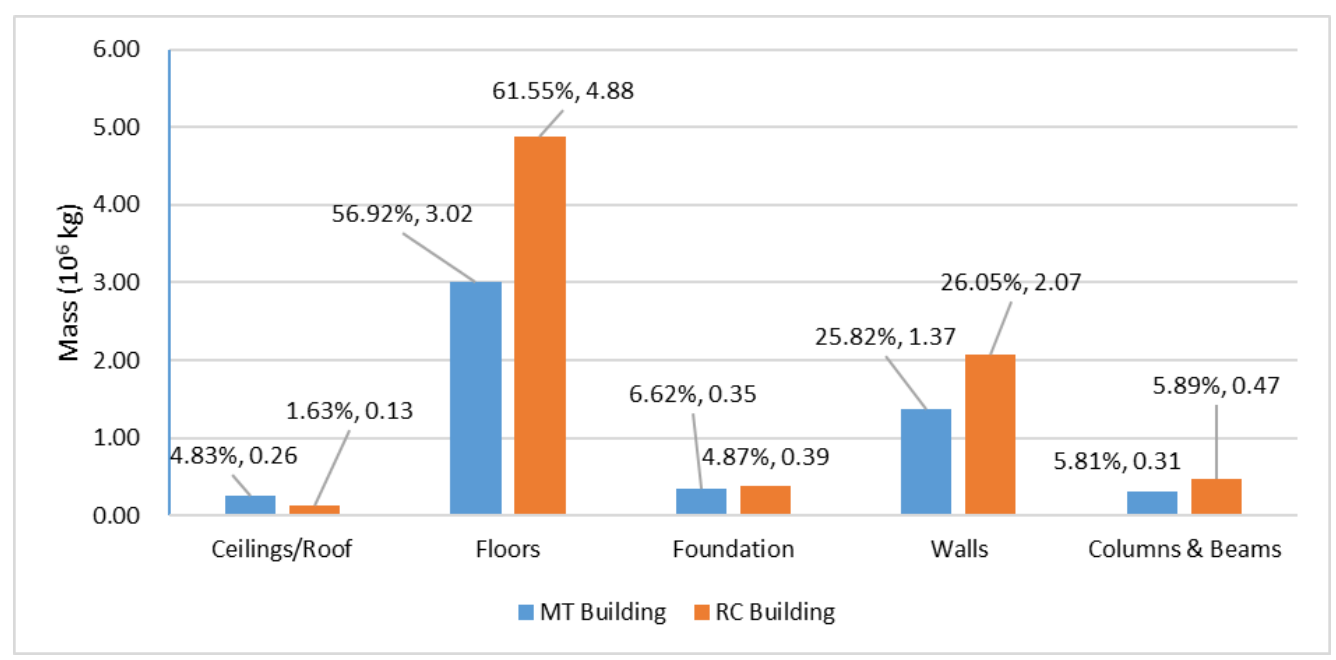

Figure 5. Mass of materials used by the different assemblies for the MT and RC buildings.

Table 1 lists specific breakdowns of material usage for the two buildings. A thin sheet of concrete is used on top of CLT floors for sound-deadening purposes. About $0.61 \times 10^{6} \mathrm{~kg}$ of CLT was in the floor assembly for the CLT building; this reduced concrete use in the floor assembly from $4.69 \times 10^{6} \mathrm{~kg}$ for the RC building to $2.33 \times 10^{6} \mathrm{~kg}$ for the CLT building. The total mass of floor materials is $3.02 \times 10^{6} \mathrm{~kg}$ in the CLT building and $4.88 \times 10^{6} \mathrm{~kg}$ in the RC building (Figure 5 and Table 1). Similarly, for walls, the total mass was $1.37 \times 10^{6} \mathrm{~kg}$ in the CLT building land $2.07 \times 10^{6} \mathrm{~kg}$ in the RC building. This was due to the use of $0.24 \times 10^{6} \mathrm{~kg}$ CLT to replace the use of $1.0 \times 10^{6} \mathrm{~kg}$ concrete and $0.11 \times 10^{6} \mathrm{~kg}$ steel, although there is $0.23 \times 10^{6} \mathrm{~kg}$ more gypsum board used in the CLT building. Additional gypsum board was required for high-rise MT buildings in the roof and walls to meet building code requirements. Table 1 was extracted from the BOM generated in the IE4B. The BOM is an ingredients list for constructing the buildings. 
The materials were classified into five groups: steel, wood, concrete, mortar, and gypsum board. CLT and glulam were classified as wood. Only the top five weighed materials are listed in Table 1, which accounted for $97.26 \%$ and $98.71 \%$ of the total mass for the MT building and RC buildings, respectively. Floors and walls make up most of the total mass in the building, so the designer may consider selecting less fossil-fuel intensive materials in building designs to reduce environmental impacts, while still meeting building code and other construction requirements.

Table 1. Grouped material for two high-rise building types by mass (Unit: $10^{6} \mathrm{~kg}$ ).

\begin{tabular}{|c|c|c|c|c|c|c|c|}
\hline Building Type & Material & Column \& Beam & Floor & Foundation & Roof & Wall & Total \\
\hline \multirow{5}{*}{ MT Building } & Steel & 0.0448 & 0.0586 & 0.0390 & 0.0177 & 0.0445 & 0.2045 \\
\hline & Wood & 0.2630 & 0.6173 & 0.0000 & 0.0005 & 0.2574 & 1.1382 \\
\hline & Concrete & 0.0000 & 2.3287 & 0.3118 & 0.0000 & 0.1889 & 2.8294 \\
\hline & Mortar & 0.0000 & 0.0054 & 0.0000 & 0.0000 & 0.1036 & 0.1091 \\
\hline & $\begin{array}{l}\text { Gypsum } \\
\text { board }\end{array}$ & 0.0000 & 0.0000 & 0.0000 & 0.2092 & 0.6628 & 0.8720 \\
\hline \multirow{5}{*}{ RC Building } & Steel & 0.0628 & 0.1736 & 0.0133 & 0.0136 & 0.1575 & 0.4208 \\
\hline & Wood & 0.0001 & 0.0033 & 0.0000 & 0.0000 & 0.0163 & 0.0197 \\
\hline & Concrete & 0.4043 & 4.6930 & 0.3729 & 0.0000 & 1.1652 & 6.6354 \\
\hline & Mortar & 0.0000 & 0.0054 & 0.0000 & 0.0000 & 0.1033 & 0.1088 \\
\hline & $\begin{array}{l}\text { Gypsum } \\
\text { board }\end{array}$ & 0.0000 & 0.0000 & 0.0000 & 0.0983 & 0.5445 & 0.6428 \\
\hline
\end{tabular}

\subsection{Life-Cycle Assessment Comparison for Environmental Impacts of the Two Buildings}

Figure 6 shows the whole building life cycle (from Module A to C, excluding maintenance, replacement, operational energy, and water use in Module B) environmental impacts of the CLT MT building and its equivalent concrete alternative. The results illustrate that the MT building had a lower environmental impact than the RC building in three of six categories: GW, OD, and EU. The MT building demonstrated $8 \%, 29 \%$, and $21 \%$ reductions in OD, EU, and GW, respectively, over its RC counterpart. The MT building had higher impacts in categories of $\mathrm{HH}, \mathrm{AC}$, and Smog (SF). Figure 7 displays the environmental impacts of each stage (excluding the operational energy emission) of the whole building LCA results. Over $75 \%$ of the total environmental loads are from the production and construction stages for both the MT and RC buildings, except HH. Future research should be focused on ways to reduce impacts of the production and construction stages.



Figure 6. Environmental impact comparison between the MT building and its RC equivalent (excluding B1, B3, B5, B6, B7). 


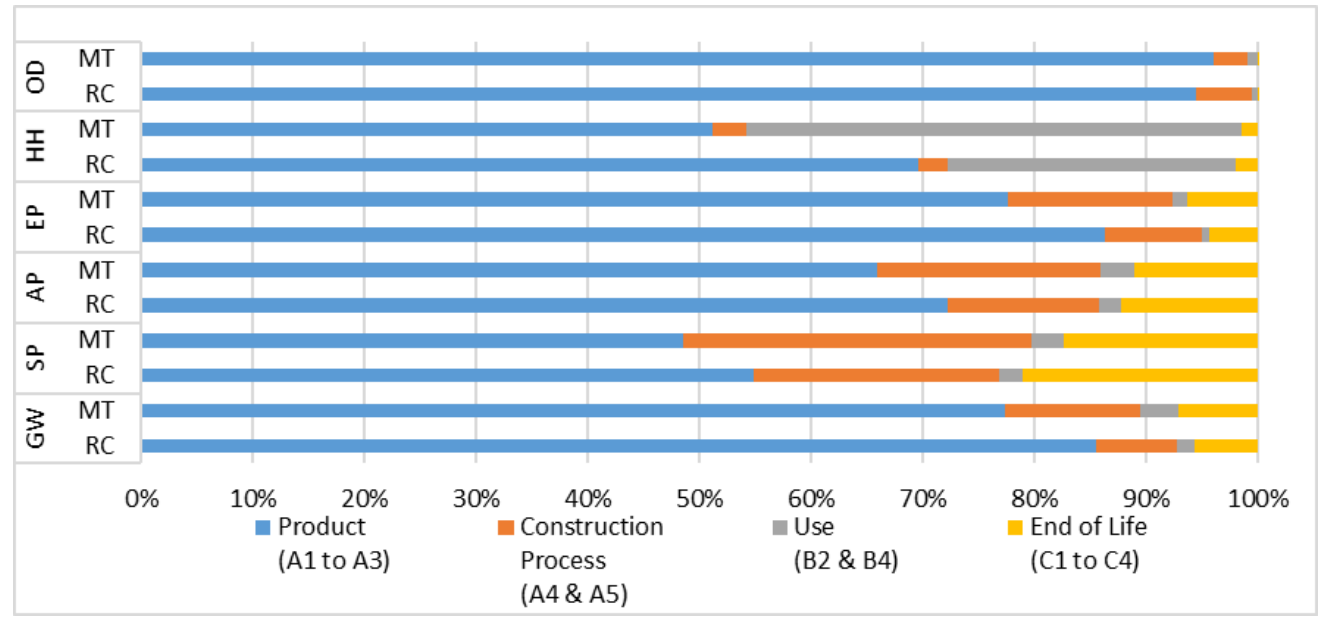

Figure 7. Source of environmental impacts from different stages of MT and RC high-rise building.

\subsection{Comparison of Global Warming Impacts}

Global warming (GW) impact is a term used to describe the contribution of a product or service to potential warming of the atmosphere, which could contribute to climate change.

\subsubsection{Global Warming Summary}

The GW impact for each life-cycle stage of each building type is shown in Table 2 and plotted in Figure 8 (for stage B, only including modules B2 and B4). In Table 2, a negative rate of change indicates that the RC building performs better than the MT building for the specific stage. The operational energy usage (B6) is the same for both buildings, according to the data provided by the architects who designed the two buildings, so the focus can be on structural elements (i.e., embodied carbon). Not including B6, total carbon dioxide emissions from modules A through $\mathrm{C}$ was about $2.15 \times 10^{7}$ $\mathrm{kg} \mathrm{CO} 2$ eq for the $\mathrm{RC}$ building and $1.70 \times 10^{7} \mathrm{~kg} \mathrm{CO}_{2}$ eq for the CLT building. When considering module $\mathrm{D}$, total carbon dioxide emissions for the RC building increased to $2.16 \times 10^{7} \mathrm{~kg} \mathrm{CO}_{2}$ eq, but it decreased to $6.57 \times 10^{6} \mathrm{~kg} \mathrm{CO}_{2}$ eq for the CLT building. Stage $\mathrm{D}$ involves reuse, recycling, and recovery of building materials. The increase of GHG emissions for the RC building is due to the carbon dioxide emissions during transportation or reuse activities. Due to the stored carbon in wood, the MT building exhibits substantially lower global warming impacts over its RC counterpart in module D.



Figure 8. Comparison of global warming impacts over life-cycle stages A-D, excluding B1, B3, B5, B6, and B7, for high rise CLT MT building and RC building. 
Table 2. Detailed comparison of global warming impact by life-cycle stage for RC and MT buildings.

\begin{tabular}{|c|c|c|c|c|c|}
\hline Stage & Process & RC & MT & $\begin{array}{c}\text { Difference }= \\
\text { RC }- \text { MT }\end{array}$ & $\begin{array}{c}\text { Rate of Change }= \\
\text { Difference/RC }\end{array}$ \\
\hline \multirow{4}{*}{$\begin{array}{l}\text { PRODUCT } \\
\text { (A1 to A3) }\end{array}$} & Unit & $\mathrm{kgCO}_{2} \mathrm{eq}$ & $\mathrm{kg} \mathrm{CO} 2 \mathrm{eq}$ & $\mathrm{kg} \mathrm{CO} 2 \mathrm{eq}$ & \\
\hline & Manufacturing & $1.82 \times 10^{6}$ & $1.28 \times 10^{6}$ & $0.54 \times 10^{6}$ & $29.7 \%$ \\
\hline & Transport & $1.96 \times 10^{4}$ & $3.62 \times 10^{4}$ & $-1.66 \times 10^{4}$ & $-84.7 \%$ \\
\hline & Total & $1.84 \times 10^{6}$ & $1.32 \times 10^{6}$ & $5.18 \times 10^{5}$ & $28.2 \%$ \\
\hline \multirow{3}{*}{$\begin{array}{l}\text { CONSTRUCTION } \\
\text { PROCESS } \\
\text { (A4 \& A5) }\end{array}$} & $\begin{array}{l}\text { Construction-Installation } \\
\text { Process }\end{array}$ & $7.47 \times 10^{4}$ & $5.09 \times 10^{4}$ & $2.38 \times 10^{4}$ & $31.9 \%$ \\
\hline & Transport & $7.95 \times 10^{4}$ & $1.55 \times 10^{4}$ & $-7.55 \times 10^{4}$ & $-95.0 \%$ \\
\hline & Total & $1.54 \times 10^{5}$ & $2.06 \times 10^{5}$ & $-5.17 \times 10^{4}$ & $-33.6 \%$ \\
\hline \multirow{5}{*}{$\begin{array}{c}\text { USE } \\
\text { (B2, B4 \& B6) }\end{array}$} & $\begin{array}{l}\text { Replacement } \\
\text { Manufacturing }\end{array}$ & $3.21 \times 10^{4}$ & $5.57 \times 10^{4}$ & $-2.36 \times 10^{4}$ & $-73.5 \%$ \\
\hline & Replacement Transport & $2.13 \times 10^{3}$ & $3.59 \times 10^{3}$ & $-1.46 \times 10^{3}$ & $-68.5 \%$ \\
\hline & B2,B4 Total & $3.42 \times 10^{4}$ & $5.93 \times 10^{4}$ & $-2.51 \times 10^{4}$ & $-73.4 \%$ \\
\hline & $\begin{array}{c}\text { Operational Energy Use } \\
\text { Total }\end{array}$ & $2.34 \times 10^{7}$ & $2.34 \times 10^{7}$ & $0.00 \times 10^{0}$ & \\
\hline & Total & $2.34 \times 10^{7}$ & $2.34 \times 10^{7}$ & $-2.51 \times 10^{4}$ & $-0.1 \%$ \\
\hline \multirow{3}{*}{$\begin{array}{l}\text { END OF LIFE } \\
(\mathrm{C} 1 \text { to } \mathrm{C} 4)\end{array}$} & $\begin{array}{c}\text { De-construction, } \\
\text { Demolition, Disposal \& } \\
\text { Waste Processing }\end{array}$ & $9.60 \times 10^{4}$ & $9.79 \times 10^{4}$ & $-0.19 \times 10^{4}$ & $-2.0 \%$ \\
\hline & Transport & $2.66 \times 10^{4}$ & $2.32 \times 10^{4}$ & $0.34 \times 10^{4}$ & $12.8 \%$ \\
\hline & Total & $1.23 \times 10^{5}$ & $1.21 \times 10^{5}$ & $1.55 \times 10^{3}$ & $1.3 \%$ \\
\hline \multirow{3}{*}{$\begin{array}{l}\text { BEYOND BUILDING } \\
\text { LIFE (D) }\end{array}$} & BBL Material & $6.49 \times 10^{3}$ & $-1.05 \times 10^{6}$ & $1.06 \times 10^{6}$ & $16332.8 \%$ \\
\hline & BBL Transport & $0.00 \times 10^{0}$ & $0.00 \times 10^{0}$ & & \\
\hline & Total & $6.49 \times 10^{3}$ & $-1.05 \times 10^{6}$ & $1.06 \times 10^{6}$ & $16332.8 \%$ \\
\hline \multirow{2}{*}{$\begin{array}{l}\text { EMBODIED } \\
\text { EMISSIONS }^{1}\end{array}$} & A to $C$ & $2.15 \times 10^{6}$ & $1.71 \times 10^{6}$ & $4.43 \times 10^{5}$ & $20.6 \%$ \\
\hline & A to $D$ & $2.16 \times 10^{6}$ & $6.57 \times 10^{5}$ & $1.50 \times 10^{6}$ & $69.5 \%$ \\
\hline \multirow{2}{*}{ TOTAL EMISSIONS ${ }^{2}$} & A to $C$ & $2.55 \times 10^{7}$ & $2.51 \times 10^{7}$ & $0.04 \times 10^{7}$ & $1.6 \%$ \\
\hline & A to $D$ & $2.55 \times 10^{7}$ & $2.40 \times 10^{7}$ & $0.15 \times 10^{7}$ & $5.9 \%$ \\
\hline
\end{tabular}

${ }^{1}$ Does not include operating energy. ${ }^{2}$ Includes operating energy.

\subsubsection{Product Stage Analysis}

Product stages A1 through A3 include raw material extraction from nature, transportation to manufacturers, and product manufacturing. Both the RC and the MT buildings produced considerable amounts of GHG emissions. According to Sjunnesson [34], the production of concrete generates the most GHG emissions in the concrete building's life cycle, which constitutes approximately $85 \%$ of its total GW impact. For the RC building, 92\% of the material mass is concrete (Figure 4), and this material accounted for $85 \%$ of total GHG emissions shown in Table 2 (emissions from A1-A3 divided by embodied emissions $\mathrm{A}-\mathrm{C}$ ). The MT building uses more wood and less concrete, so GHG emissions were $5.18 \times 10^{5} \mathrm{~kg} \mathrm{CO}_{2}$ eq (Table 2) less than the RC building, or $28.2 \%$ less than the RC building.

\subsubsection{Construction Stage Analysis}

The construction stage includes transportation of materials from factory to construction site by truck or rail (A4) and construction work, such as product installation and groundwork (A5). Table 2 shows that $1.55 \times 10^{5} \mathrm{~kg} \mathrm{CO}_{2}$ eq and $5.09 \times 10^{4} \mathrm{~kg} \mathrm{CO}_{2}$ eq emissions resulted from transportation and construction, respectively, for the MT building; these values for the $\mathrm{RC}$ building were $7.95 \times 10^{4} \mathrm{~kg} \mathrm{CO}_{2}$ eq and $7.47 \times 10^{4} \mathrm{~kg} \mathrm{CO}_{2}$ eq, respectively. GHG emissions from this stage were lower than from the product stage. This is because the Framework building has not been built, so the practical construction onsite energy use is not available, but the IE4B default fossil fuel energy use calculation for crane operation was included only in this stage of environmental impacts. For the RC building, the construction stage 
GHG emissions are only 7.1\% (emissions from A4 to A5 divided by embodied emissions from A to C) of its total embodied carbon, whereas for the MT building it is about $11.7 \%$. The reason for there being more carbon emissions from the MT building than from the $\mathrm{RC}$ building is the greater distance between the CLT manufacturer and the construction site. For concrete, given its weight and extensive use in urban areas, providers are normally within 25 miles of the building site, so the transportation of concrete tends to consume less fossil fuel than transportation of MT materials. There are limited CLT manufacturers in the United States and Canada, which leads to longer transportation distances and results in higher impacts for the MT building for A4. As additional CLT and other MT product manufacturers arise, these transportation distances will tend to shorten, resulting in lower A4 impact for MT buildings. Furthermore, the lighter weight of CLT building materials leads to lower GHG emissions during erection of the building structure compared to the RC building.

\subsection{Use Stage Analysis}

The use stage includes only maintenance (Module B2), replacement (Module B4), and Operational Energy (Module B6). Modules B1 (Use), B3 (Repair), B5 (Refurbishment), and B7 (Operational Water) are all excluded, due to the assumption of functional equivalency for the two buildings and a lack of empirical data for B3-Repair and B5-Refurbishing for MT buildings. Repair and Refurbishing of a building in the use stage can make an impact in GWP if the waste stream from repair and refurbishing is significant. However, for the current paper, due to the lack of such data from this new building sector, they are excluded, but only including the maintenance components (B2) and replacing building materials (B4). Both the MT and RC buildings produced very small amounts of GHG emissions for modules B2 and B4 (Table 2), about $0.1 \%$ and $0.2 \%$ of their total embodied carbon from cradle to grave (A to C). Carbon emissions in this stage from the MT building were a little higher than those from the $\mathrm{RC}$ building, because the wood requires more maintenance to meet fire codes and prevent moisture intrusion into the building envelope.

\subsection{End of Life Stage Analysis}

The end of life stage includes energy use of the demolition equipment (C1), materials transportation from site to landfill (C2), waste sorting and processing (C3), and disposal equipment energy use (C4). Carbon emissions in this stage from the MT building and the RC building are only slightly different, $1.21 \times 10^{5} \mathrm{~kg} \mathrm{CO}_{2}$ eq and $1.23 \times 10^{5} \mathrm{~kg} \mathrm{CO}_{2}$ eq, respectively (Table 2). This means that, although the mass of materials used in the MT building was less than that in the RC equivalent, the two buildings consumed a similar amount of energy at the end of building life stage.

\subsection{Beyond Building Life Stage}

Stage D quantifies the net environmental benefits or loads due to reuse, recycling, and energy recovery resulting from the net flows of materials and energy exported beyond the system boundary. A biogenic carbon accounting methodology is adopted in IE4B, in accordance with the internationally accepted carbon footprint standards: PAS 2050 [35], ISO 14067 [36], and WRI GHG Protocol [37] for Products. According to the principle of these three standards, if the forest will be renewed after logging, forest growth leads to the reduction of carbon dioxide in the atmosphere, which is considered negative carbon emission [38]. Figure 9 demonstrates the negative carbon emissions derived in stage D for the large quantity of CLT used in the MT building. This carbon benefit has also been demonstrated in another paper [8]. Overall, the CLT wood product has a positive GW impact when considering carbon storage in products' life. For every cubic meter of CLT (380 oven dry kg wood) used in the MT building, about $190 \mathrm{~kg}$ of carbon are stored, which is equivalent to $700 \mathrm{~kg} \mathrm{CO}$.

Table 2 shows the embodied GHG emissions in relation to module D (beyond building life). Including D, it shows that the MT building produced $69.5 \%$ less GHG emissions than the RC building compared to $20.6 \%$ from stages A through C. When considering building operating energy, these numbers drop to $5.9 \%$ and $1.6 \%$, respectively. This indicates the importance of building operating 
energy along with masking the importance of structural element material. For module $\mathrm{D}$, the wood products used in the building exhibited an environmental carbon savings of $1.05 \times 10^{6} \mathrm{~kg} \mathrm{CO}_{2}$ eq from the carbon stored (Figure 9).

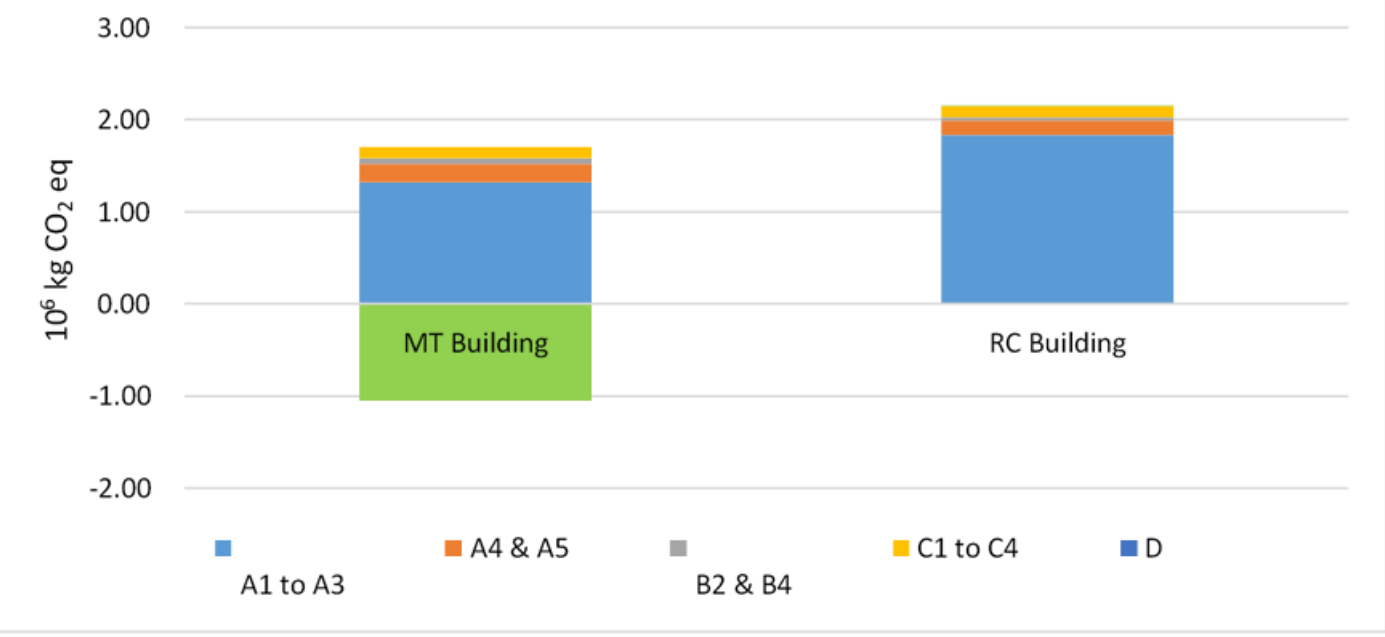

Figure 9. Global warming impact for each building by life-cycle stage.

\section{Comparison of Global Warming Impact by Building Assembly Groups}

Figure 10 shows the GHG emissions by assembly groups for the two building types from Stage A to D. GHG emissions were mainly from wall and floor for the RC building, in which floors accounted for almost $50 \%$ and wall accounted for $36 \%$ of its total emissions. For the MT building, floors accounted for only $24 \%$, and walls accounted for $58 \%$ of its total carbon emissions. The value of GHG emissions from MT building walls and floors were dramatically reduced by $50 \%$ and $80 \%$ from the RC building assemblies, respectively. This is due to the large amount of CLT substituting concrete and steel, as shown in the materials summary of Figure 5 and Table 1 . Therefore, in building construction, replacing traditional concrete and steel materials with CLT mass timber materials as structural members results in significant environmental benefits.

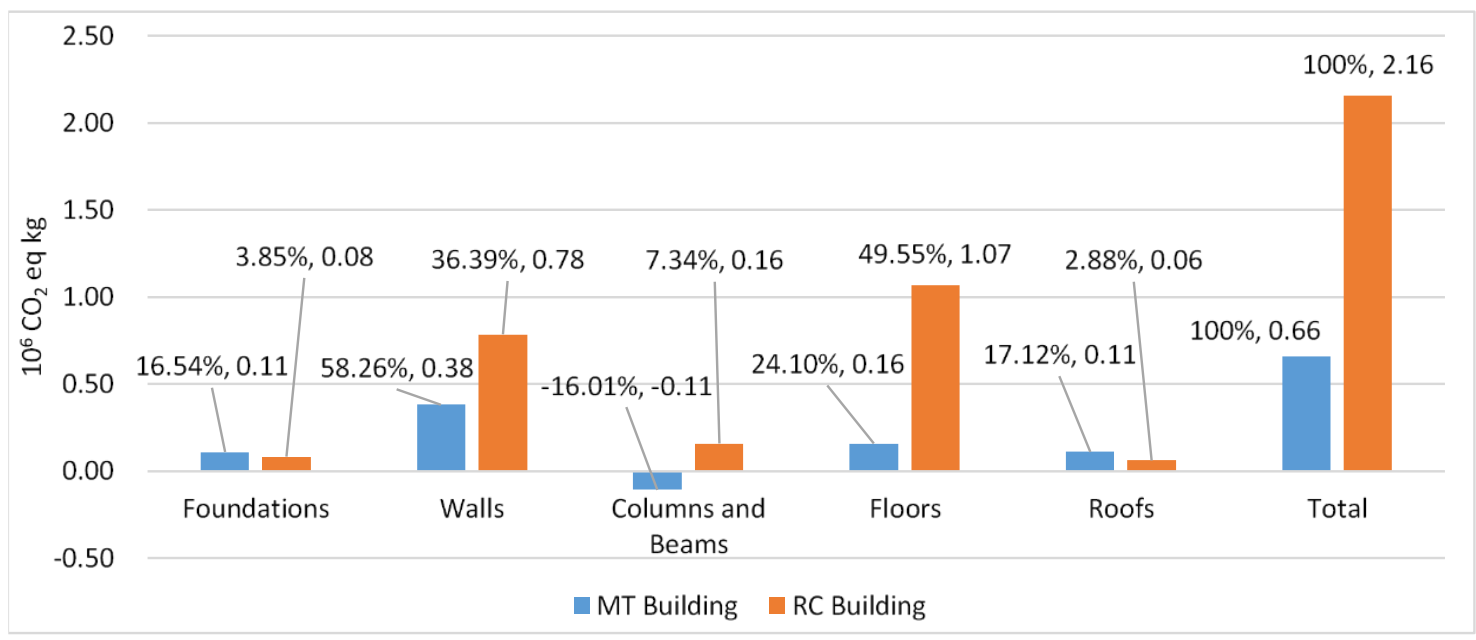

Figure 10. Comparison of global warming impact (from A to D) by assembly group for the two buildings. 


\section{Conclusions}

This study conducted a comparative whole-building LCA of two functionally equivalent high-rise buildings using the Athena IE4B. The designs were based on the Framework building in Portland, Oregon, USA. For material resource efficiency, the MT building weighed about $67 \%$ of its RC equivalent, a substantial advantage for mass timber building designs. GW, AC, EU, and other impact indicators were reported from the whole-building LCA from cradle-to-grave analysis. Results showed that substituting wood for concrete and steel in these buildings would bring significant GHG emission reductions. From Stages A through C, the embodied carbon was $21 \%$ lower for the MT building due to these substitutions. If considering carbon stored by the CLT material in the MT building, then the GHG emissions reduction would increase to $69.5 \%$. This comparative study demonstrated CLT as a smart choice for structural frames, such as walls and floors, compared to traditional concrete and steel building materials.

Research focusing on reducing emissions in the building sector has shifted from improving operational energy use and its associated emissions through efficiency measures to the selection of low-carbon-footprint materials for better environmental influence. Buildings constructed with wood products are considered to have low environmental loads, especially if carbon stored effects are considered. The results reported in this paper can support decision makers seeking better choices of material for high-rise buildings, in order to minimize environmental burdens and mitigate climate change.

Author Contributions: Conceptualization, Z.C., H.G. and S.L.; methodology, Z.C. and S.L.; software, Z.C.; validation, H.G. and S.L.; formal analysis, Z.C.; investigation, Z.C., H.G. and S.L.; resources, H.G. and R.D.B.; data curation, S.L. and Z.C.; writing — original draft preparation, Z.C.; writing—review and editing, H.G. and R.D.B.; supervision, H.G. and R.D.B.; project administration, H.G.; funding acquisition, R.D.B. All authors have read and agreed to the published version of the manuscript.

Funding: This project is financially supported by a joint venture agreement between the USDA Forest Service Forest Products Laboratory and the U.S. Endowment for Forestry \& Communities, Inc., Endowment Green Building Partnership-Phase 1, no. 16-JV-11111137-094.

Acknowledgments: The authors acknowledge English editing and reviewing work by James Anderson, Publication Manager at USDA Forest Products Laboratory and Matthew Arvanitis at USDA Forest Products Laboratory, Economics, Statistics and Life Cycle Analysis research group.

Conflicts of Interest: The authors declare no conflict of interest.

\section{Appendix A}

Table A1. Total Building Material Quantities for Each Building Design.

\begin{tabular}{|c|c|c|c|}
\hline Materials Used in Different Assemblies & Unit & Amount CLT ${ }^{1}$ Building & Amount Concrete Building \\
\hline \multicolumn{4}{|l|}{ Materials-Ceilings/Roof } \\
\hline Acoustic ceiling tile & $\mathrm{m}^{2}$ & 220.4 & 228.6 \\
\hline Cold formed structural steel & tonne & 11.4 & 7.4 \\
\hline Cross laminated timber & $\mathrm{m}^{3}$ & 1.1 & 0.0 \\
\hline Mineral wool; high density & $\mathrm{m}^{2}(25 \mathrm{~mm})$ & 295.7 & 295.7 \\
\hline Paint; interior acrylic latex & $\mathrm{L}$ & 2657.0 & 1328.4 \\
\hline Polystyrene board (XPS); Pentane foaming agent & $\mathrm{m}^{2}(25 \mathrm{~mm})$ & 104.6 & 104.6 \\
\hline Steel; sheet & tonne & 5.7 & 5.7 \\
\hline Suspended grid & tonne & 0.4 & 0.4 \\
\hline Wall board; gypsum; fire-resistant (Type X) & $\mathrm{m}^{2}$ & 14907.0 & 5945.4 \\
\hline Wall board; gypsum; natural & $\mathrm{m}^{2}$ & 4153.8 & 3336.7 \\
\hline
\end{tabular}


Table A1. Cont.

\begin{tabular}{|c|c|c|c|}
\hline Materials Used in Different Assemblies & Unit & Amount CLT ${ }^{1}$ Building & Amount Concrete Building \\
\hline \multicolumn{4}{|l|}{ Materials-Floors } \\
\hline Adhesive; acrylic & tonne & 0.1 & 0.1 \\
\hline Cement grout; Cement mortar & $\mathrm{m}^{3}$ & 2.5 & 2.5 \\
\hline Coated steel deck & tonne & 0.1 & 0.1 \\
\hline Cold formed structural steel & tonne & 0.4 & 0.4 \\
\hline Cross laminated timber & $\mathrm{m}^{3}$ & 1278.7 & 0.0 \\
\hline Exterior grade plywood & $\mathrm{m}^{2}(9 \mathrm{~mm})$ & 699.0 & 699.0 \\
\hline Polystyrene board (XPS); Pentane foaming agent & $\mathrm{m}^{2}(25 \mathrm{~mm})$ & 2948.8 & 2948.8 \\
\hline Steel; reinforcing rod & tonne & 53.2 & 170.3 \\
\hline Steel; sheet & tonne & 4.2 & 0.9 \\
\hline Steel; welded wire mesh & tonne & 0.1 & 0.1 \\
\hline Structural concrete & $\mathrm{m}^{3}$ & 961.6 & 1937.9 \\
\hline TPO membrane & $\mathrm{m}^{2}$ & 351.5 & 351.5 \\
\hline \multicolumn{4}{|l|}{ Materials-Foundation } \\
\hline Structural concrete & $\mathrm{m}^{3}$ & 128.7 & 154.0 \\
\hline Steel; reinforcing rod & tonne & 38.6 & 13.1 \\
\hline \multicolumn{4}{|l|}{ Materials-Columns and Beams } \\
\hline Glue laminated timber & $\mathrm{m}^{3}$ & 557.1 & 0.0 \\
\hline Cold formed structural steel & tonne & 43.1 & 38.8 \\
\hline Hot rolled structural steel & tonne & 0.4 & 0.4 \\
\hline Composite wood I-joist & $\mathrm{m}^{2}(9 \mathrm{~mm})$ & 12.5 & 12.5 \\
\hline Structural concrete & $\mathrm{m}^{3}$ & 0.0 & 166.9 \\
\hline Steel; reinforcing rod & tonne & 0.0 & 22.1 \\
\hline Steel; sheet & tonne & 0.8 & 0.8 \\
\hline \multicolumn{4}{|l|}{ Materials-Walls } \\
\hline Aluminum extrusion & tonne & 4.6 & 4.6 \\
\hline Aluminum-faced composite wall panel, sheet, siding & tonne & 26.4 & 26.4 \\
\hline Cold formed structural steel & tonne & 31.9 & 30.0 \\
\hline Concrete masonry unit (CMU); hollow-core & blocks & 3132.6 & 3127.1 \\
\hline Cross laminated timber (CLT) & $\mathrm{m}^{3}$ & 502.0 & 0.0 \\
\hline Exterior grade plywood; US & $\mathrm{m}^{2}(9 \mathrm{~mm})$ & 3418.5 & 3418.5 \\
\hline Mortar type S & $\mathrm{m}^{3}$ & 4.5 & 4.5 \\
\hline Thickset mortar & $\mathrm{m}^{3}$ & 43.2 & 43.1 \\
\hline Paint; interior acrylic latex & $\mathrm{L}$ & 7809.6 & 4413.7 \\
\hline Polystyrene board (XPS); Pentane foaming agent & $\mathrm{m}^{2}(25 \mathrm{~mm})$ & 5541.2 & 5541.9 \\
\hline Sealant; silicone & tonne & 0.6 & 0.6 \\
\hline Steel; reinforcing rod & tonne & 12.1 & 126.0 \\
\hline Structural concrete & $\mathrm{m}^{3}$ & 49.2 & 452.4 \\
\hline Wall board; gypsum; fire-resistant (Type X) & $\mathrm{m}^{2}$ & 57330.3 & 47096.9 \\
\hline
\end{tabular}

\footnotetext{
${ }^{1}$ Specific gravity of the cross-laminated timber is 0.380 .
}

\section{References}

1. Hafner, A. Contribution of timber buildings on sustainability issues. In Proceedings of the World Sustainable Building 2014, Barcelona, Spain, 28-30 October 2014.

2. Sandanayake, M.; Lokuge, W.; Zhang, G.; Setunge, S.; Thushar, Q. Greenhouse gas emissions during timber and concrete building construction-A scenario based comparative case study. Sustain. Cities Soc. 2018, 38, 91-97. [CrossRef]

3. Abergel, T.; Dean, B.; Dulac, J. Towards a Zero-Emission, Efficient, and Resilient Buildings and Construction Sector: Global Status Report 2017; UN Environment and International Energy Agency: Paris, France, 2017.

4. Bribián, I.Z.; Uson, A.A.; Scarpellini, S. Life cycle assessment in buildings: State-of-the-art and simplified LCA methodology as a complement for building certification. Build. Environ. 2009, 44, 2510-2520. [CrossRef] 
5. Zabalza Bribián, I.; Valero Capilla, A.; Aranda Usón, A. Life cycle assessment of building materials: Comparative analysis of energy and environmental impacts and evaluation of the eco-efficiency improvement potential. Build. Environ. 2011, 46, 1133-1140. [CrossRef]

6. Smedley, T. Timber Structures Would Allow Us to Draw Carbon from the Air and Store It in Our Homes and Offices-Leading Some to Believe That Wooden Buildings Are the Future of Architecture. Available online: http://www.bbc.com/future/story/20190717-climate-change-wooden-architecture-concrete-globalwarming (accessed on 29 July 2019).

7. Worldsteel Position Paper, Steel's Contribution to a Low Carbon Future and Climate Resilient Societies. Available online: https://www.worldsteel.org/publications/position-papers/steel-s-contribution-to-a-lowcarbon-future.html (accessed on 29 July 2019).

8. Svensson, E.; Panojevic, D. A Life Cycle Assessment of the Environmental Impacts of Cross-Laminated Timber. MA. Eng. Thesis, Lund University, Lund, Sweden, January 2019.

9. McKeever, D.B.; Elling, J. Wood Products Other Building Materials Used in New Residential Construction in the United States; APA—The Engineered Wood Assoc: Tacoma, WA, USA, 2015; p. 131.

10. Sahoo, K.; Bergman, R.; Alanya-Rosenbaum, S.; Gu, H.; Liang, S. Life cycle assessment of forest-based products: A review. Sustainability 2019, 11, 4722. [CrossRef]

11. Howard, J.L.; Liang, S. U.S. Timber Production, Trade, Consumption, and Price Statistics, 1965-2017; Res. Pap. FPL-RP-701; U.S. Department of Agriculture, Forest Service, Forest Products Laboratory: Madison, WI, USA, 2019; p. 106.

12. Pierobon, F.; Huang, M.; Simonen, K.; Ganguly, I. Environmental benefits of using hybrid CLT structure in midrise non-residential construction: An LCA based comparative case study in the US Pacific Northwest. J. Build. Eng. 2019, 26, 100862. [CrossRef]

13. Ritter, M.; Skog, K.; Bergman, R. Science Supporting the Economic and Environmental Benefits of Using Wood and Wood Products in Green Building Construction; General Technical Report FPL-GTR-206; U.S. Department of Agriculture, Forest Service, Forest Products Laboratory: Madison, WI, USA, 2011; pp. 1-9.

14. Dong, Y.; Qin, T.; Zhou, S.; Huang, L.; Bo, R.; Guo, H.; Yin, X. Comparative Whole Building Life Cycle Assessment of Energy Saving and Carbon Reduction Performance of Reinforced Concrete and Timber Stadiums-A Case Study in China. Sustainability 2020, 12, 1566. [CrossRef]

15. Bergman, R.; Puettmann, M.; Taylor, A.; Skog, K.E. The Carbon Impacts of Wood Products. Forest Prod. For. Prod. J. 2014, 64, 220-231.

16. Green, M.C.; Karsh, J.E. The Case for Tall Wood Buildings-How Mass Timber Offers a Safe, Economical, and Environmentally Friendly Alternative for Tall Building Structures; Prepared by: mgb ARCHITECTURE + DESIGN; Equilibrium Consulting, LMDG Ltd., BTY Group: Vancouver, BC, Canana, 22 February 2012.

17. Werner, F.; Taverna, R.; Hofer, P.; Richter, K. Carbon pool and substitution effects of an increased use of wood in buildings in Switzerland: First estimates. Ann. For. Sci. 2005, 62, 889-902. [CrossRef]

18. Bergman, R.D.; Falk, R.H.; Gu, H.; Napier, T.R.; Meil, J. Life-Cycle Energy and GHG Emissions for New and Recovered Softwood Framing Lumber and Hardwood Flooring Considering End-of-Life Scenarios; Res. Pap. FPL-RP-672; U.S. Department of Agriculture, Forest Service, Forest Products Laboratory: Madison, WI, USA, 2013; p. 35.

19. Kutnar, A.; Hill, C. Life Cycle Assessment-Opportunities for Forest Products Sector. Bioprod. Bus. 2017, 2, 52-64.

20. Dagenais, C.; White, R.H.; Sumathipala, K. Fire: Fire Performance of Cross-Laminated Timber Assemblies. In CLT Handbook: Cross-Laminated Timber/Edited by Erol Karacabeyli, Brad Douglas (US Edition); U.S. Department of Agriculture, Forest Service, Forest Products Laboratory: Madison, WI, USA; Binational Softwood Lumber Council: Surrey, BC, Canada, 2012; p. 55, Chapter 8; ISBN 978-0-86488-553-1.

21. Grasser, K.K. Development of cross Laminated Timber in the United States of America. Master's Thesis, University of Tennessee, Knoxville, TN, USA, 2015.

22. Robertson, A.B. A Comparative Life Cycle Assessment of Mid-Rise Office Building Construction Alternatives: Laminated Timber or Reinforced Concrete. Ph.D. Thesis, University of British Columbia, Vancouver, BC, Canada, 2011.

23. Williamson, T.; Ross, R. Proceedings: Mass Timber Research Workshop 2015; General Technical Report FPL-GTR-241; U.S. Department of Agriculture, Forest Service, Forest Products Laboratory: Madison, WI, USA, 2016; pp. 1-364. 
24. Zelinka, S.L.; Williamson, T.; Martinson, K.L.; Ritter, M.A. Research Needs Assessment for the Mass Timber Industry: Proceedings of the 2nd North American Mass Timber Research Needs Workshop; Gen. Tech. Rep. FPL-GTR-273; U.S. Department of Agriculture, Forest Service, Forest Products Laboratory: Madison, WI, USA, 2019; p. 41.

25. Darby, H.; Elmualim, A.A.; Kelly, F. A Case Study to Investigate the Life Cycle Carbon Emissions and Carbon Storage Capacity of a cross Laminated Timber, Multi-Storey Residential Building; SB13: Munich, Germany, 24-26 April 2013.

26. Skullestad, J.L.; Bohne, R.A.; Lohne, J. High-Rise Timber Buildings as a Climate Change Mitigation Measure-A Comparative LCA of Structural System Alternatives. Energy Procedia 2016, 96, 112-123. [CrossRef]

27. Milaj, K.; Sinha, A.; Miller, T.H.; Tokarczyk, J.A. Environmental utility of wood substitution in commercial buildings using life-cycle analysis. Wood Fiber Sci. 2017, 49, 338-358.

28. Gu, H.; Bergman, R. Life Cycle Assessment and Environmental Building Declaration for the Design Building at the University of Massachusetts; General Technical Report FPL-GTR-255; US Forest Service, Forest Products Laboratory: Madison, WI, USA, February 2018; p. 71.

29. ASMI. Impact Estimator for Buildings Version 5.4.01 Software; Athena Sustainable Material Institute: Ottawa, ON, Canada. Available online: https://calculatelca.com/software/impact-estimator (accessed on 21 November 2019).

30. EN. 15978 Sustainability of Construction Works-Assessment of Environmental Performance of Buildings_Calculation Method; European Committee for Standardisation: Brussels, Belgium, 2011.

31. Bare, J.C. TRACI 2.0: The tool for the reduction and assessment of chemical and other environmental impacts 2.0. Clean Technol. Environ. Policy 2011, 13, 687-696. [CrossRef]

32. Sathre, R.; O'Connor, J. Meta-analysis of greenhouse gas displacement factors of wood product substitution. Environ. Sci. Policy 2010, 13, 104-114. [CrossRef]

33. Nepal, P.; Skog, K.E.; McKeever, D.B.; Bergman, R.D.; Abt, K.L.; Abt, R.C. Carbon mitigation impacts of increased softwood lumber and structural panel use for nonresidential construction in the United States. For. Prod. J. 2016, 66, 77-87. [CrossRef]

34. Sjunnesson, J. Life Cycle Assessment of Concrete. MA. Eng. Thesis, Lund University, Lund, Sweden, September 2005.

35. PAS 2050:2011. Specification for the assessment of the life cycle greenhouse gas emissions of goods and services. Bsi Br. Stand. Isbn 2008, 978, 580 .

36. ISO 14067:2018. Greenhouse Gases: Carbon Footprint of Products: Requirements and Guidelines for Quantification and Communication; ISO: Geneva, Switzerland, 2017.

37. Bhatia, P.; Cummis, C.; Draucker, L.; Rich, D.; Lahd, H.; Brown, A. Greenhouse Gas Protocol, Product Life Cycle Accounting and Reporting Standard; World Resources Institute: Washington, DC, USA, 2011.

38. ASMI. Impact Estimator for Buildings V. 5 User Manual and Transparency Document; Athena Sustainable Material Institute: Ottawa, ON, Canada, 2019; Available online: https://calculatelca.com/wp-content/uploads/2019/05/ IE4B_v5.4_User_Guide_May_2019.pdf (accessed on 21 November 2019).

(C) 2020 by the authors. Licensee MDPI, Basel, Switzerland. This article is an open access article distributed under the terms and conditions of the Creative Commons Attribution (CC BY) license (http://creativecommons.org/licenses/by/4.0/). 